\section{Response of Baby Spinach (Spinacia oleracea L.) to Photoselective Nettings on Growth and Postharvest Quality}

\author{
Ambani R. Mudau \\ Department of Life and Consumer Sciences, College of Agriculture and \\ Environmental Sciences, University of South Africa, Private Bag X6, Florida \\ 1710, South Africa
}

\section{Puffy Soundy \\ Department of Crop Sciences, Tshwane University of Technology, Private Bag X680, Pretoria 0001}

\section{Fhatuwani N. Mudau ${ }^{1}$ \\ Department of Agriculture and Animal Health, College of Agriculture and Environmental Sciences, University of South Africa, Private Bag X6, Florida 1710, South Africa}

Additional index words. antioxidant activity, sensory quality, shade nets, flavonoids

\begin{abstract}
Manipulation of microenvironments by means of photoselective nettings is widely used to improve the productivity and quality of high-value vegetables. The aim of this study was to investigate the effect of photoselective nettings on growth, productivity, and postharvest quality attributes of baby spinach. Baby spinach cv. Ohio was grown from seeds, and the trial was repeated. Plants were planted in an open field (control) and under closed nets, viz., black, pearl, yellow, and red nets. At harvest, baby spinach leaves were subjected to 4,10 , and $20^{\circ} \mathrm{C}$ storage temperatures for 12 days. Crops grown under black nets and stored at $4{ }^{\circ} \mathrm{C}$ retained higher level of antioxidant activity $\left(0.23 \mathrm{~g} \cdot \mathrm{kg}^{-1}\right)$, whereas the least level of antioxidant activity was observed in baby spinach grown under red and yellow shade nets $\left(0.01 \mathrm{~g} \cdot \mathrm{kg}^{-1}\right)$. Similar trend was evident with flavonoid content where baby spinach leaves grown under black nets maintained high level of flavonoids at 4,10 , and $20^{\circ} \mathrm{C}$ during storage period compared with other shade nets and the control. The study control showed a better potential in retaining antioxidant activity over red and yellow shade nets. Results showed that black shade nettings have the potential to reduce water loss, decay incidents, and maintain flavonoid content and antioxidant activity followed by pearl and yellow nets.
\end{abstract}

Recently, the demand for baby spinach (Spinacia oleracea L.) far exceeds the supply because of its health attributes and ease to use as leafy vegetable (Cocetta et al., 2014). Baby spinach is grown all year round in temperate regions (Rodríguez-Hidalgo et al., 2010). Baby spinach is considered to contain relatively high amounts of carotenoids (Bergquist et al., 2006), flavonoids, and phenolic acids (Fallovo et al., 2009). These biological compounds are reported to reduce chronic diseases, viz., heart-related diseases (Shashirekha et al., 2015), prostate cancer (Neuhouser, 2004), and dementia (Commenges et al., 2000).

The recent rise in global warming across the world has posed severe challenges to crop production. Among others, the challenges include increase in air temperature (AT)

Received for publication 23 Feb. 2017. Accepted for publication 4 Apr. 2017.

This work was financially supported by the Gauteng Department of Agriculture and Rural Development (GDARD; GUN no. 359000).

${ }^{1}$ Corresponding author. E-mail: mudaufn@unisa.ac. za. and intensity of solar radiation (Meena et al., 2014). Thus, more advanced and innovative practices are required to mitigate such challenges with less energy cost. The most efficient method will possibly be the use of shade nets because they can modify environmental conditions. Photoselective nets have been used to improve crop productivity and protect against pests and physical damages (Selahle et al., 2014).

Owing to adverse climate change, agronomic practices such as shade netting have been established in the past decade with the aim of filtering selective regions of the spectrum from natural radiation (Stamps, 2009). The use of colored shade nets creates favorable microclimate and provides physical protection to the crops (Oren-Shamir et al., 2001; Shahak et al., 2008), thereby improving the quality of vegetables.

The acceptability of processed produce by consumers relies on two fundamental quality parameters, visual appearance and texture (Toivonen and Brummell, 2008). Cultural practices such as sowing and harvest time (Bergquist et al., 2007a), irrigation (Pellegrini et al., 2003), mineral nutrition (Zikalala et al.,
2016), industrial processing (Hodges and Toivonen, 2008), and postharvest storage temperature and duration (Mudau et al., 2015) have been reported to improve nutritional quality of baby spinach. Meena et al. (2014) demonstrated that light intensity, incoming radiation, and canopy temperature were significantly reduced under protected shade nets. Bergquist et al. (2007a) reported that shade nettings reduced flavonoid concentration in baby spinach ranging between $15 \%$ and $24 \%$. In another study conducted by Bergquist et al. (2007b), baby spinach grown under shade nets showed significantly higher concentrations of total carotenoids and total chlorophylls. The authors further observed that the effect of shade nettings also significantly decreased ascorbic acid concentration. Data that describe the effect of a wide range of photoselective colored nets on the postharvest quality of baby spinach are lacking in South Africa. Therefore, the aim of this study was to investigate the effect of photoselective nettings on growth, productivity, and postharvest quality attributes of baby spinach.

\section{Materials and Methods}

Experimental sites. The experiments were conducted at Tshwane University of Technology Experimental Farm located in Bon Accord, north of Pretoria, at lat. $50^{\circ} 37^{\prime} \mathrm{S}$, long. $28^{\circ} 12^{\prime} \mathrm{E}^{\prime \prime}$, and altitude $1173 \mathrm{~m}$ above sea level; the site received low summer rainfall $(160.6 \mathrm{~mm})$ and high temperature $\left(>35{ }^{\circ} \mathrm{C}\right)$ for two consecutive seasons, viz., 2013 and 2014, respectively.

Plant material. Ohio baby spinach cultivar [Hygrotech (Pty) Ltd., Pretoria, South Africa] were grown from seeds on $10 \mathrm{Dec}$. 2013, and the trial was repeated on 18 Nov. 2014 within a glasshouse with the temperature controlled using a pad and fan system. Seedlings were thinned after $12 \mathrm{~d}$ of sowing. Growing bags with seedlings were spaced at $30 \times 30 \mathrm{~mm}$ and subjected to photoselective colored shade nettings [ChromatiNet; Polysac Plastics Industries (Pty) Ltd., Israel] and open field (exposure to full sunlight).

Treatment and experimental design details. Five treatments consisted of open field (control), black, pearl, yellow, and red net arranged in a randomized complete block design with three blocks assigned to each of the five treatments. All trials were repeated twice. The shading intensities of pearl, yellow, and red nets were $40 \%$, whereas that of black net was $25 \%$. Plants were fertilized with a balanced nutrient solution as described by Nemadodzi et al. (2016). All plants were dripirrigated. Drip irrigation was controlled by a computerized irrigation system, and it was two drippers per bag. One dripper had a discharge rate of $23.4 \mathrm{~mL} \cdot \mathrm{min}^{-1}$ (per bag it was $46.8 \mathrm{~mL} \cdot \mathrm{min}^{-1}$ ) at $3 \mathrm{~h}$ intervals, five times a day.

After $35 \mathrm{~d}$ of sowing, all plants were harvested, and leaves were washed using running water, dried using ventilation fan, and packed in perforated $150 \mathrm{~mm}^{2}$ plastic 

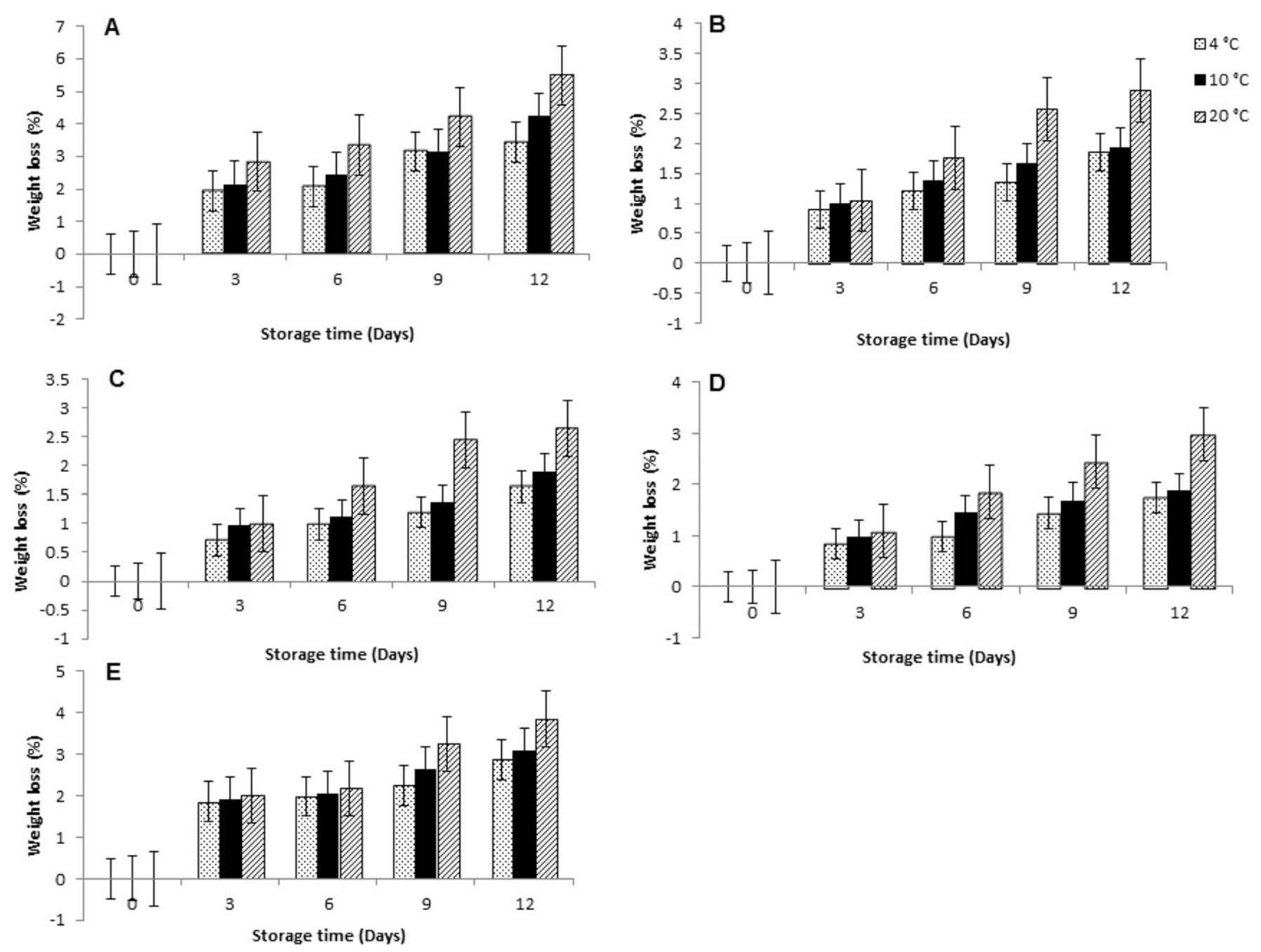

Fig. 1. Percentage cumulative weight loss of baby spinach grown under (A) black, (B) red, (C) pearl, (D) yellow, and (E) open field and stored at 4,10 and $20{ }^{\circ} \mathrm{C}$ for $12 \mathrm{~d}$. Data points indicate mean weight loss standard error.

Table 1. Effect of photoselective nets on petiole and leaf parameters of baby spinach.

\begin{tabular}{lccccc}
\hline Nets & $\begin{array}{c}\text { Petiole } \\
\text { length }(\mathrm{cm})\end{array}$ & Leaf width $(\mathrm{cm})$ & Leaf length $(\mathrm{cm})$ & Large $^{\mathrm{z}}$ leaves $(\%)$ & $\begin{array}{c}\text { Leaf chlorophyll } \\
\text { (SPAD units) }\end{array}$ \\
\hline Black & $3.5 \mathrm{~b}$ & $3.3 \mathrm{~b}$ & $6.2 \mathrm{~b}$ & 5 & $66.32 \mathrm{a}$ \\
Red & $4.3 \mathrm{a}$ & $3.6 \mathrm{~b}$ & $7.5 \mathrm{a}$ & 6 & $56.38 \mathrm{~b}$ \\
Pearl & $4.1 \mathrm{a}$ & $3.5 \mathrm{~b}$ & $7.0 \mathrm{a}$ & 6 & $53.67 \mathrm{~b}$ \\
Yellow & $4.9 \mathrm{a}$ & $4.2 \mathrm{a}$ & $7.9 \mathrm{a}$ & 10 & $56.53 \mathrm{~b}$ \\
No net & $3.6 \mathrm{~b}$ & $3.1 \mathrm{~b}$ & $5.5 \mathrm{c}$ & 0 & $50.45 \mathrm{~b}$ \\
\hline
\end{tabular}

Means in the same column followed by different letters indicate significance $(P<0.05)$ using Duncan's multiple range test. Leaves and petioles were measured after $35 \mathrm{~d}$ of sowing before termination of trial. ${ }^{\mathrm{z}}$ Leaves having petiole length equal to, or longer than $10 \mathrm{~cm}$.

Table 2. PAR, AT, and RH measurements under different photoselective nets and open-field conditions.

\begin{tabular}{lrrr}
\hline Nets & $P A R\left(\mu \mathrm{mol} \cdot \mathrm{m}^{-2} \cdot \mathrm{s}^{-1}\right)$ & $\mathrm{AT}\left({ }^{\circ} \mathrm{C}\right)$ & $\mathrm{RH}(\%)$ \\
\hline Black & $1,224.33 \pm 75.06 \mathrm{~b}^{2}$ & $32.7 \pm 6.5 \mathrm{~b}$ & $50.16 \pm 14.1 \mathrm{a}$ \\
Red & $768.91 \pm 10.52 \mathrm{~d}$ & $33.9 \pm 8.4 \mathrm{~b}$ & $39.1 \pm 11.3 \mathrm{~b}$ \\
Pearl & $855.16 \pm 64.85 \mathrm{c}$ & $33.4 \pm 7.9 \mathrm{~b}$ & $35.9 \pm 9.6 \mathrm{~b}$ \\
Yellow & $745.98 \pm 69.23 \mathrm{~d}$ & $38.1 \pm 8.5 \mathrm{a}$ & $33.6 \pm 8.3 \mathrm{~b}$ \\
Open field (control) & $1,561.00 \pm 80.19 \mathrm{a}$ & $40.0 \pm 12.6 \mathrm{a}$ & $25.0 \pm 5.5 \mathrm{c}$ \\
\hline
\end{tabular}

$P A R=$ photosynthetically active radiation; $\mathrm{AT}=$ air temperature; $\mathrm{RH}=$ relative humidity.

Means in the same column followed different letters indicate significance $(P<0.05)$ using Duncan's multiple range test.

${ }^{\mathrm{z}}$ Values are means followed by standard deviation.

containers. The baby spinach perforated containers were further stored at 4,10 , or $20^{\circ} \mathrm{C}$ for $0,2,4,6,8$, or $12 \mathrm{~d}$, and the samples were freeze-dried.
Data collected. The following data were collected: weight loss, morphological quality (leaf length, petiole length, and leaf width), leaf chlorophyll, microenvironment analysis, total flavonoids, antioxidant activity, and sensory quality (overall acceptance, flavor/ taste, and odor). Descriptions on the data collected are provided below.

Weight loss. Baby spinach leaves were weighed using a digital electronic balance [Model MK-500C, DENVER Instrument ( $\pm 0.001 \mathrm{~g})$; Sigma-Aldrich, St. Louis, MO] at the beginning and end of each storage period. Data were expressed as percentage weight loss.

Morphological quality and leaf chlorophyll. Parameters recorded during growing stages were petiole length, leaf length, leaf width, and leaf chlorophyll. Fifteen random plants per shade net or open field were measured after $35 \mathrm{~d}$ of sowing. Plant petiole length, leaf length, and leaf width were measured in centimeters $(\mathrm{cm})$ using a Vernier caliper (Mitutoyo Corporation, Japan). Leaf chlorophyll content was measured nondestructively using a SPAD 502 chlorophyll meter (Konica Minolta Co. Ltd., Japan).

Microenvironment analysis. The measurements of light spectra and microclimate parameters under nets were determined using the method described by 
Shahak et al. (2004). Photosynthetically active radiation $(P A R)$ outside and under the nets were measured with a model LP-80 Ceptometer AccuPAR (Decagon Devices Ltd., Pullman, WA). Radiation, AT, and relative humidity (RH) were measured using Tinytag $\mathrm{T} / \mathrm{RH}$ data loggers (Gemini Data Loggers Ltd., Chichester, UK) placed above the plant canopy at $1.5 \mathrm{~m}$ from the ground, and they were protected against direct solar radiation and rain.

Total flavonoid assay. The calorimetric protocol of Yoo et al. (2008) and slightly modified by Mudau et al. (2015) was followed to determine the total flavonoids of the baby spinach extracts.

Antioxidant activity assay. The Trolox equivalent antioxidant capacity assay described by Awika and Rooney (2004) and slightly modified by Mudau et al. (2015) was used to determine antioxidant activity (by free radical scavenging) of the baby spinach extracts.

Sensory analysis (overall appearance, flavor/taste, and odor). Product quality was evaluated in fresh harvested material and after $3,6,9$, and $12 \mathrm{~d}$ of storage. An interval of a few days was opted to be able to depict any changes immediately. Sensory attributes were scored based on the methods described by Zhan et al. (2012). In this method, the overall acceptance, flavor/taste, and odor evaluation were carried out by 10 trained panelists between 23 and 45 years of age $(70 \%$ females and $30 \%$ males $)$. The panelists evaluated the overall acceptance of the fresh product at each storage interval. In an assessment of postharvest decay condition, samples were individually scored in accordance to a structured scale (from 1 to 5 ), where $5=$ excellent, $4=\operatorname{good}($ some leaves were slightly yellow or decayed), $3=$ fair (with acceptable marketability), $2=$ poor (dominated by yellow or decayed leaves), and 1 = extremely poor (inedible). With regard to odor, a scale of 1 to 5 was applied (where $5=$ excellent, $4=$ slightly off-odor, 3 = moderate off-odor, 2 = strong off-odor, and 1 = intolerable off-odor). In determining flavor, a scale of $5=$ sweet, $4=$ mild sweet, $3=$ slightly sweet, $2=$ bitter/ sour, and $1=$ poor taste (not tasted avoiding risks of microorganisms contamination) was used. A score below 3 for any of these sensory attributes was considered to be of unacceptable marketability.

Statistical analysis. Data were subjected to analysis of variance using IBM SPSS statistics version 23.0. The Pearson's correlation was performed to determine the relationship between the treatments and variables. The Wilcoxon-Mann-Whitney test was used for sensory analysis in comparison of treatments applied during postharvest. The significant difference was considered when $P<0.05$.

\section{Results}

Weight loss. Weight loss observed during the storage period significantly varied with respect to different shade nets. However, the loss never exceeded $5.5 \%$ in all treatments (Fig. 1A-E). At day 3 of storage, spinach leaves grown under the pearl net and stored at $4{ }^{\circ} \mathrm{C}$ resulted in the least weight loss $(0.72 \%)$. The plants grown under the black net had significant weight loss reaching $2.85 \%$ when stored at $20{ }^{\circ} \mathrm{C}$. After $9 \mathrm{~d}$ of storage, plants grown under the black net had significantly more weight loss $(4.23 \%)$ than other plants grown under nets and in an open field, whereas plants grown under the pearl net shade had the lowest weight loss of $1.2 \%$. Generally, plants subjected to the black net across all storage temperature were found to have the highest weight loss than all
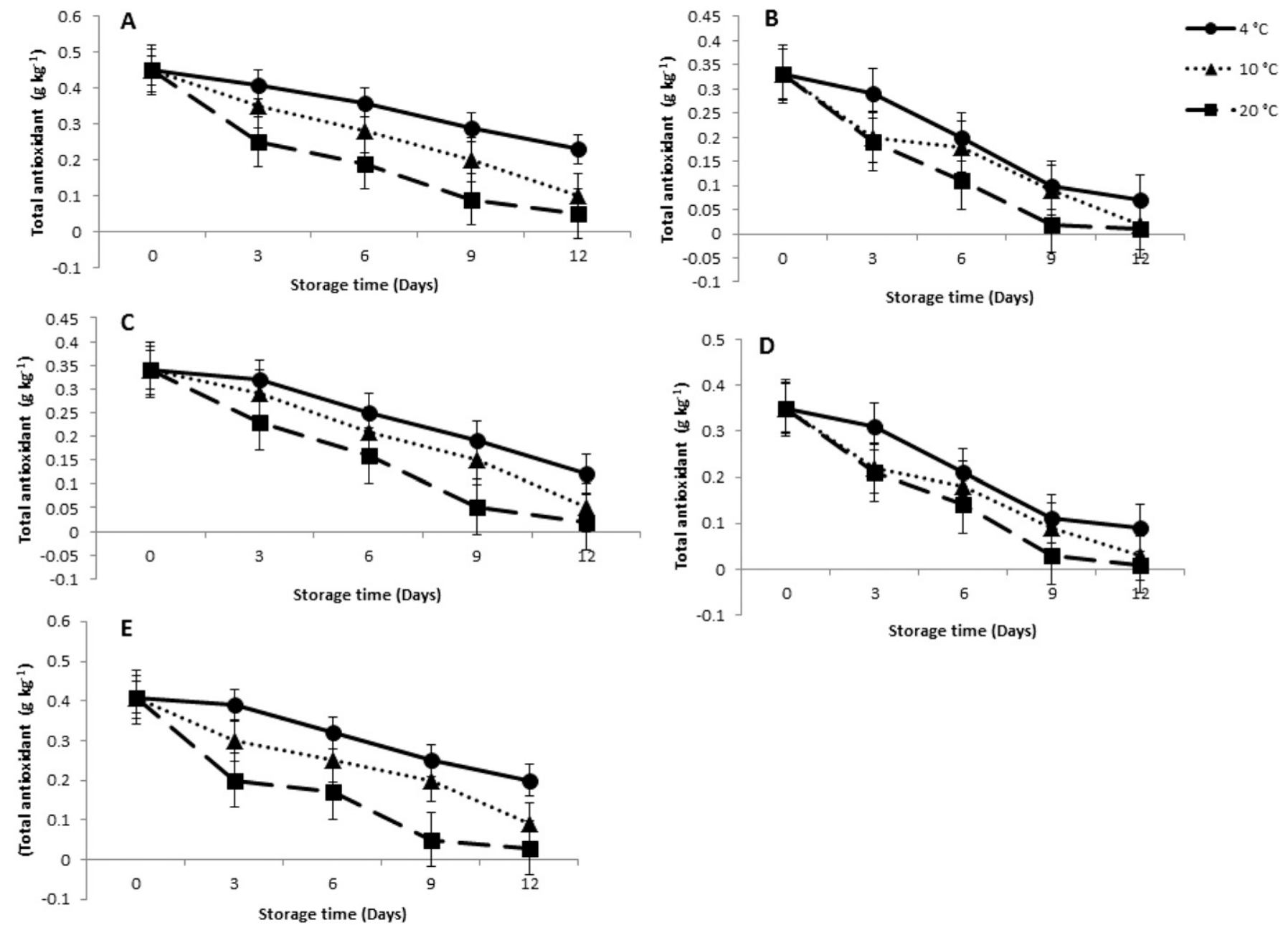

Fig. 2. Total antioxidant activity in the baby spinach leaves grown under $(\mathbf{A})$ black, (B) red, $(\mathbf{C})$ pearl, (D) yellow, and $(\mathbf{E})$ open field and stored at 4,10 and $20{ }^{\circ} \mathrm{C}$ for $12 \mathrm{~d}$. Data points indicate mean total antioxidant content standard error. 
treatments. Overall, the least weight loss $(0.72 \%)$ was observed in plants grown under the pearl net and stored at $4{ }^{\circ} \mathrm{C}$, whereas the highest weight loss $(5.5 \%)$ was observed in plants grown under the black net and stored at $20{ }^{\circ} \mathrm{C}$. No significant differences were observed in plants grown under red, pearl, and yellow nets at 4,10 , and $20^{\circ} \mathrm{C}$, respectively. However, plants grown under the black net showed a significant weight loss $(P<0.05)$ compared with plants grown under red, pearl, and yellow nets (Fig. 1A-E).

Morphological quality and leaf chlorophyll. Table 1 shows that baby spinach grown under photoselective nets except for the black net had significantly longer leaf petiole than those grown in an open-field condition. Pearl, red, and yellow nets exhibited longer leaf petiole than the black net.

Red, pearl, and yellow nets exhibited significant difference $(P>0.05)$ in petiole length, leaf length, and large leaves. Plants grown in the open field produced the least leaf width $(3.1 \mathrm{~cm})$ and leaf length $(5.5 \mathrm{~cm})$. High leaf chlorophyll was observed in the black net $\left(66.32 \mu \mathrm{mol} \cdot \mathrm{m}^{-2}\right)$ followed by red $\left(56.38 \mu \mathrm{mol} \cdot \mathrm{m}^{-2}\right)$ and yellow $\left(56.53 \mu \mathrm{mol} \cdot \mathrm{m}^{-2}\right)$ nets (Table 1).

Microenvironment analysis. Baby spinach plants grown under field conditions were subjected to higher $P A R$ of $1561.00 \mu \mathrm{mol} \cdot \mathrm{m}^{-2} \cdot \mathrm{s}^{-1}$ than plants grown under colored shade nets (Table 2). The open field was followed by the black net with $1224.33 \mu \mathrm{mol} \cdot \mathrm{m}^{-2} \cdot \mathrm{s}^{-1}$. Pearl net had higher $P A R$ than both red and yellow nets. However, the $P A R$ was least pronounced in the yellow net with a value of $745.98 \mu \mathrm{mol} \cdot \mathrm{m}^{-2} \cdot \mathrm{s}^{-1}$. The highest AT was recorded in the open field at $40{ }^{\circ} \mathrm{C}$, whereas the lowest AT was observed in the black shade net with $32{ }^{\circ} \mathrm{C}$. Both red and yellow nets had AT of $33.9{ }^{\circ} \mathrm{C}$ and $38.1{ }^{\circ} \mathrm{C}$, respectively. The lowest RH was observed in the open field $(25.0 \%)$, whereas the highest RH was observed under the black net $(50.2 \%)$. The red net had a $\mathrm{RH}$ of $39.1 \%$ followed by the pearl net $(35.9 \%)$ and yellow net $(33.6 \%)$ (Table 2).

Total antioxidant activity. Shade nets in combination with storage temperature affected the total antioxidant activity (TAA) at harvest and during postharvest storage (Fig. 2). At harvest, TAA was found to be higher in spinach grown under the black net $\left(0.45 \mathrm{~g} \cdot \mathrm{kg}^{-1}\right)$, whereas the least activity was pronounced in baby spinach grown under the red net with a TAA content of $0.33 \mathrm{~g} \cdot \mathrm{kg}^{-1}$ (Fig. 2A and B). Baby spinach grown in the open field at harvest had $0.41 \mathrm{~g} \cdot \mathrm{kg}^{-1}$ TAA which was higher than the TAA found in spinach grown under the yellow net $\left(0.35 \mathrm{~g} \cdot \mathrm{kg}^{-1}\right)$, pearl net $\left(0.34 \mathrm{~g} \cdot \mathrm{kg}^{-1}\right)$, and red net $\left(0.33 \mathrm{~g} \cdot \mathrm{kg}^{-1}\right.$; Fig. 4B-E). During the storage period, samples stored at $4{ }^{\circ} \mathrm{C}$ showed much better capacity of retaining higher TAA than other samples stored at $10^{\circ} \mathrm{C}$ and $20^{\circ} \mathrm{C}$ irrespective of the growing conditions. At $6 \mathrm{~d}$ of storage, the highest TAA content was observed in baby spinach grown under the black net $\left(0.36 \mathrm{~g} \cdot \mathrm{kg}^{-1}\right)$ followed by baby spinach grown in the open field $\left(0.32 \mathrm{~g} \cdot \mathrm{kg}^{-1}\right)$ when stored at $4{ }^{\circ} \mathrm{C}$. Baby spinach grown under the black net and stored at $10{ }^{\circ} \mathrm{C}$ showed a higher TAA content $\left(0.28 \mathrm{~g} \cdot \mathrm{kg}^{-1}\right)$ than those grown under the pearl net $\left(0.25 \mathrm{~g} \cdot \mathrm{kg}^{-1}\right)$, yellow net $\left(0.21 \mathrm{~g} \cdot \mathrm{kg}^{-1}\right)$, and red net $\left(0.20 \mathrm{~g} \cdot \mathrm{kg}^{-1}\right)$ when stored at $4{ }^{\circ} \mathrm{C}$. Among the
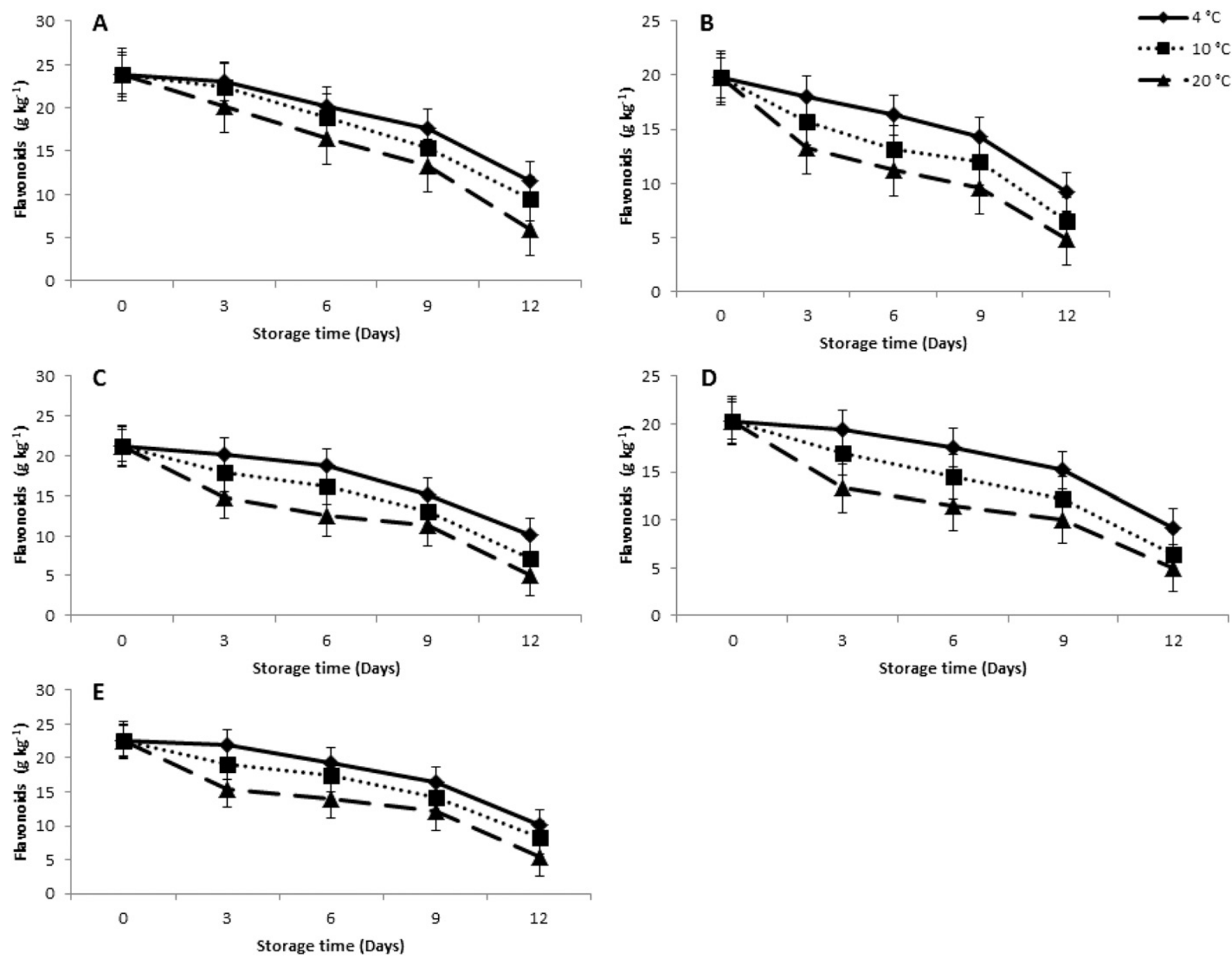

Fig. 3. Flavonoids in the baby spinach leaves grown under (A) black, (B) red, (C) pearl, (D) yellow, and (E) open field and stored at 4,10 and $20{ }^{\circ} \mathrm{C}$ for 12 d. Data points indicate mean flavonoids standard error. 
shade nets, spinach grown under the black net showed significantly higher $(P<0.05)$ flavonoids than the other nets when stored in different temperatures as the storage duration progressed. However, no significant difference $(P>0.05)$ was observed in the TAA content of baby spinach grown under pearl, red, and yellow shade nettings during storage duration (Fig. 2A-E).

Total flavonoids content. The effect of shade nets and storage temperature on flavonoids showed a similar trend to that observed in TAA. At harvest, spinach grown under the black net had higher flavonoid content $\left(23.85 \mathrm{~g} \cdot \mathrm{kg}^{-1}\right)$ than those grown in the open field $\left(22.55 \mathrm{~g} \cdot \mathrm{kg}^{-1}\right)$ and under the pearl net
(21.25 $\left.\mathrm{g} \cdot \mathrm{kg}^{-1}\right)$, yellow net $\left(20.32 \mathrm{~g} \cdot \mathrm{kg}^{-1}\right)$, and red net $\left[19.74 \mathrm{~g} \cdot \mathrm{kg}^{-1}\right.$ (Fig. 3A-E)]. There was no consistent declining rate between the shade nets and flavonoid content during storage duration. Higher temperature $\left(20^{\circ} \mathrm{C}\right)$ led to great loss in flavonoid content as storage duration progressed. After $6 \mathrm{~d}$ of storage, spinach grown under the black net and stored at $4{ }^{\circ} \mathrm{C}$ showed higher flavonoid content than spinach grown under other nets and in the open field when stored at 4, 10, and $20{ }^{\circ} \mathrm{C}$. Baby spinach grown under the black net had significantly higher $(P<0.05)$ flavonoid content than those grown under red, pearl, and yellow nets when stored in all three different temperatures. Baby spinach

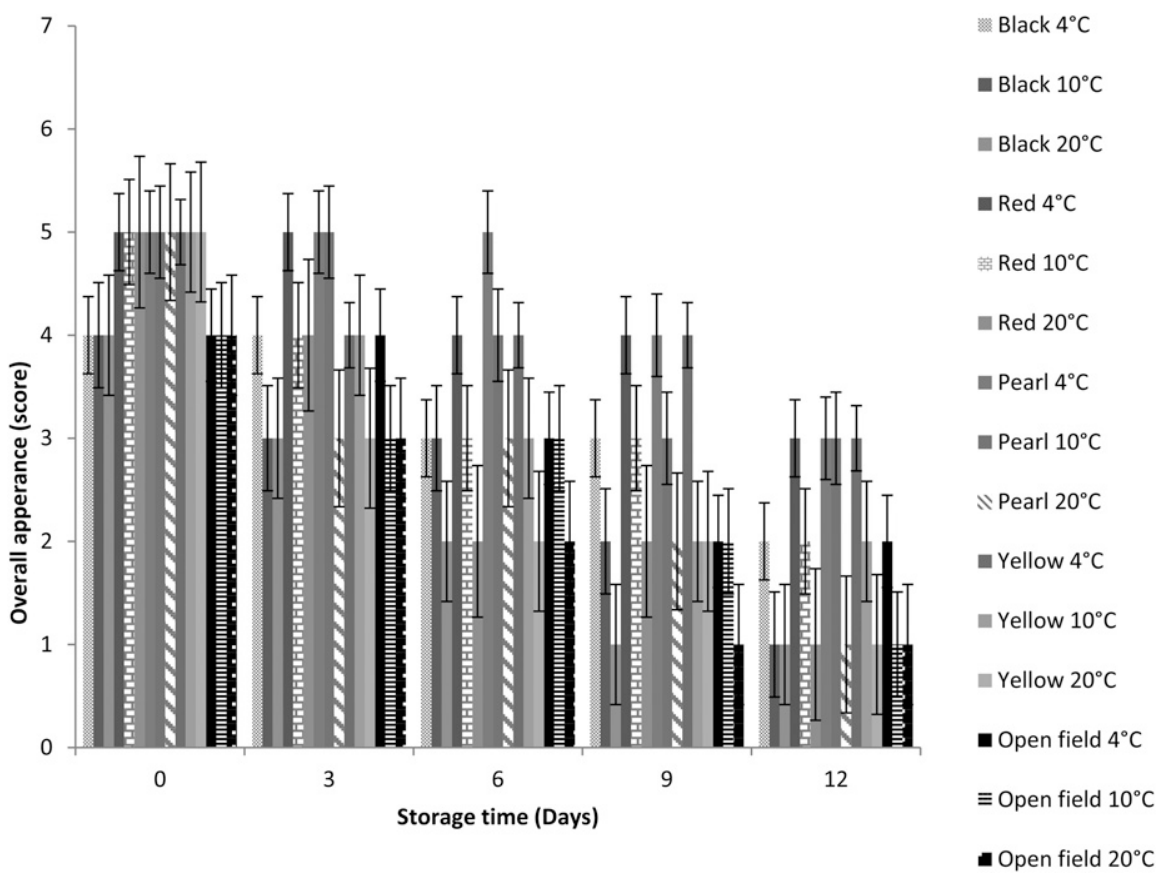

Fig. 4. Influence of photoselective nets on overall appearance in baby spinach leaves stored at 4,10 and $20{ }^{\circ} \mathrm{C}$ for $12 \mathrm{~d}$. Data points indicate mean score standard error. grown under the red, pearl, and yellow nets did not show significant differences in flavonoids when stored at 4,10 , and $20^{\circ} \mathrm{C}$. After $12 \mathrm{~d}$ of storage, the baby spinach grown under the black net had better capacity to retain the flavonoid content than those grown under other nets or without net. After $12 \mathrm{~d}$ of storage, the highest content of flavonoid was observed in spinach stored at $4{ }^{\circ} \mathrm{C}$ when grown under the black net followed by those grown in the open field (10.01 g. $\left.\mathrm{kg}^{-1}\right)$ and pearl net $\left(10.10 \mathrm{~g} \cdot \mathrm{kg}^{-1}\right)$. At the end of trial, the lowest flavonoid content was observed in spinach stored at $20^{\circ} \mathrm{C}$, when grown under the yellow net $(4.95$ $\left.\mathrm{g} \cdot \mathrm{kg}^{-1}\right)$ and red net $\left(4.85 \mathrm{~g} \cdot \mathrm{kg}^{-1}\right)$ (Fig. 3A-E).

Overall appearance. Results in Fig. 4 show that the quality of the baby spinach grown under black and pearl nets was greatly acceptable (using visual appearance quality) than those of that were grown under red and yellow nets. Baby spinach grown in the open field exhibited poor visual appearance after $6 \mathrm{~d}$ of storage.

Flavor and odor. Black, pearl, and yellow nets maintained better flavor of baby spinach leaves than those grown in the open field at 4 and $10{ }^{\circ} \mathrm{C}$ for $12 \mathrm{~d}$ (Fig. 5A). Baby spinach grown in the open field and red shade nettings achieved slightly off-odor state when stored at $4{ }^{\circ} \mathrm{C}$ for $12 \mathrm{~d}$ (Fig $5 \mathrm{~B})$. Both black and yellow shade nettings maintained moderate off-odor at $4{ }^{\circ} \mathrm{C}$ for $12 \mathrm{~d}$. Strong off-odor was noted after $12 \mathrm{~d}$ of storage at $4{ }^{\circ} \mathrm{C}$ in baby spinach leaves grown under the pearl shade netting (Figs. 4 and 5A and $\mathrm{B}$ ).

\section{Discussion}

There are limited research reports on baby spinach grown in a wide range of colored shade nets. The current findings showed reduced weight loss and significant decay in spinach grown under the pearl net. The improved vegetative growth is most pronounced
A

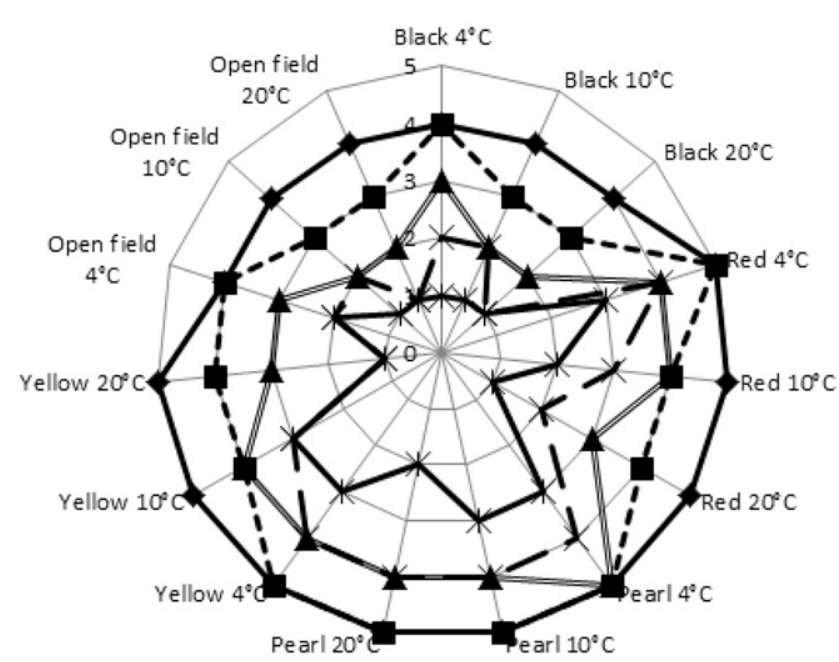

B

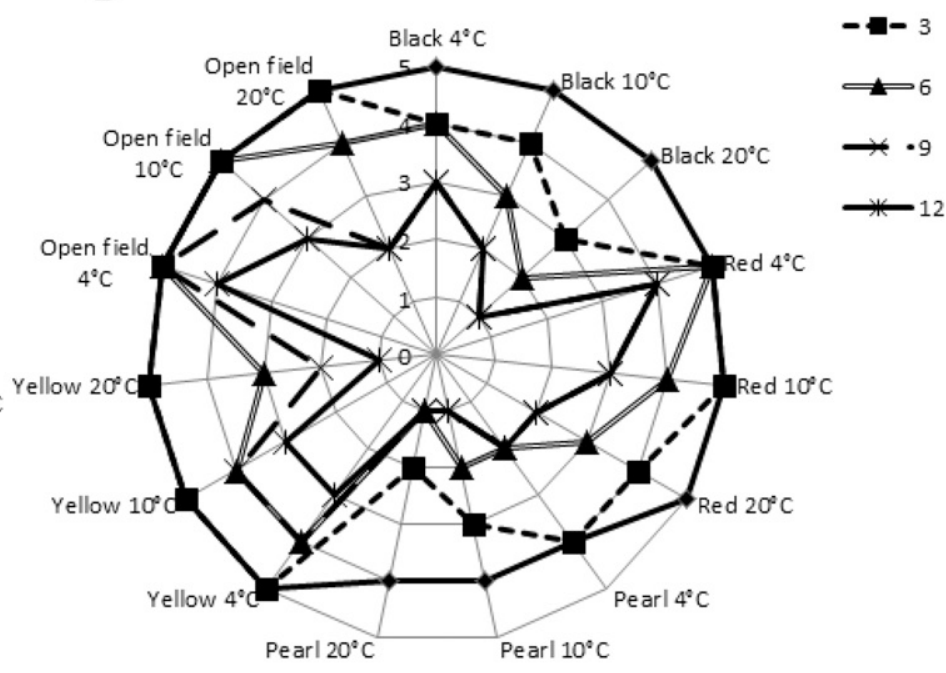

Fig. 5. Influence of photoselective nets on the (A) flavor and (B) odor in baby spinach leaves stored at 4, 10, and $20{ }^{\circ} \mathrm{C}$ for $12 \mathrm{~d}$. 
in plants grown under shade nets in comparison with plants grown in the open field. Iglesias and Alegre (2006) reported that the increase in $\mathrm{RH}$, lower maximum temperature, and lower wind speed within the protected environment reduces incidence of water loss and subsequent reduction in decay. These extreme conditions let unprotected plants being exposed to high heat stress, particularly baby spinach which requires cool conditions for better growth and development. Oren-Shamir et al. (2001) reported that black and red nets promote elongation during growth and development processes.

Shade nets are mainly deployed over crops to lessen heat stress (Shahak et al., 2004). Photoselective nets are regarded as nets which prevent excess radiation and improve the soil moisture levels that promote proper plant growth. This improves the productivity (yield) of the plant and, arguably, retains the best quality of leaves during postharvest storage. The reduction of radiation and AT is responsible for a great deal in regulating the photosynthetic capacity of leaves and, consequently, a reduced light saturated photosynthetic rate unlike in the open field (Medany et al., 2008). Ilić et al. (2015) observed similar findings when plants under the black net had higher chlorophyll content than other selected photoselective nettings. According to Shahak et al. (2008), lettuce (Lactuca sativa) and basil (Ocimum basilicum) had significantly increased production when subjected to the red and pearl nets over those grown under aluminet, blue, or black nets.

Phenolic compounds are major constituents of antioxidant properties of fresh produce (Gil et al., 2002). With the lack of data that describe the physiological responses of baby leaf spinach on phytochemicals on pearl as photoselective net, the present findings exhibited an improved antioxidant activity compared with plants grown under a pearl net.

It is known that the response of individual crop species to harmful ultraviolet-B radiation can differ considerably in the process of flavonoid synthesis (Harborne and Williams, 2000). Quercetin and its glycosides are extensively evaluated flavonoids for their biological activities (Proteggente et al., 2002). This is evident in our findings that there is similar response of antioxidant activity and flavonoids in baby spinach. Conversely, Bergquist et al. (2007a) reported that there was an increase in the flavonoids in spinach grown under shade during storage period. This increase was attributed to induced stress caused by shade and, as a result, increased flavonoid concentration.

In conclusion, the results of this study demonstrated that the black net reduces water loss and decay incidents, and maintains the content of flavonoid and antioxidant activity followed by pearl and yellow nets, respectively. The results also suggested that photoselective shade nets technology can be recommended when growing baby spinach particularly under black, pearl, and yellow nets when baby spinach leaves are stored at $4{ }^{\circ} \mathrm{C}$ during storage.

\section{Literature Cited}

Awika, J.M. and L.W. Rooney. 2004. Sorghum photochemical and their stability in sunflower oil and emulsion. Food Chem. 64:323-329.

Bergquist, S.A.M., U.E. Gertsson, and M.E. Olsson. 2006. Influence growth stage and postharvest storage on ascorbic acid and carotenoid content and visual quality of baby spinach (Spinacia oleracea L.). J. Sci. Food Agr. 86:346-355.

Bergquist, S.A.M., U.E. Gertsson, L.Y.G. Nordmark, and M.E. Olsson. 2007a. Effects of shade nettings, sowing time and storage on baby spinach flavonoids. J. Sci. Food Agr. 87:2464 2471.

Bergquist, S.A.M., U.E. Gertsson, L.Y.G. Nordmark, and M.E. Olsson. 2007b. Ascorbic acid, carotenoids, and visual quality of baby spinach as affected by shade netting and postharvest storage. J. Sci. Food Agr. 55:8444-8451.

Cocetta, G., V. Baldassarre, A. Spinardi, and A. Ferrante. 2014. Effect of cutting on ascorbic acid oxidation and recycling in fresh-cut baby spinach (Spinacia oleracea L.) leaves. Postharvest Biol. Technol. 88:8-16.

Commenges, D., V. Scotet, S. Renaud, H. JacqminGadda, P. Barberger-Gateau, and J.F. Dartigues. 2000. Intake of flavonoids and risk of dementia. Eur. J. Epidemiol. 16:357-363.

Fallovo, C., Y. Rouphael, E. Rea, A. Battistelli, and G. Colla. 2009. Nutrient solution concentration and growing season affect yield and quality of Lactuca sativa $\mathrm{L}$. var. acephala in floating raft culture. J. Sci. Food Agr. 89:1682-1689.

Gil, M.I., F.A. Tomás-Barberán, B. Hess-Pierce, and A.A. Kader. 2002. Antioxidant capacities, phenolic compounds, carotenoids, and vitamin $\mathrm{C}$ contents of nectarine, peach, and plum cultivars from California. J. Agr. Food Chem. 50:4976-4982.

Harborne, J.B. and C.A. Williams. 2000. Advances in flavonoid research since 1992. Phytochemistry 55:481-504.

Hodges, D.M. and P.M. Toivonen. 2008. Quality of fresh-cut fruits and vegetables as affected by exposure to abiotic stress. Postharvest Biol. Technol. 48:155-162.

Iglesias, I. and S. Alegre. 2006. The effect of antihail nets on fruit protection, radiation, temperature, quality and profitability of 'Mondial Gala' apples. J. Applied Hort. 8:91-100.

Ilić, Z.S., L. Milenković, L. Šunić, and E. Fallik 2015. Effect of coloured shade-nets on plant leaf parameters and tomato fruit quality. J. Sci. Food Agr. 95:2660-2667.

Medany, M.A., M.K. Hassanein, and A.A. Farag. 2008. Effect of black and white nets as alternative covers to sweet pepper production under greenhouses in Egypt. International Symposium on Strategies Towards Sustainability of Protected Cultivation in Mild Winter Climate. 807:121-126.

Meena, R.K., A. Vashisth, R. Singh, B. Singh, and K.M. Manjaih. 2014. Study on change in microenvironment under different colour shade nets and its impact on yield of spinach (Spinacia oleracea L.). J. Agromet. 16:104-111.

Mudau, A.R., M. Nkomo, P. Soundy, H.T. Araya, W. Ngezimana, and F.N. Mudau. 2015. Influence of post-harvest storage temperature and duration on quality of baby spinach. HortTechnology 25:665-670.
Nemadodzi, L., H. Araya, M. Nkomo, W. Ngezimana, and F.N. Mudau. 2016. Response of physiological and biomass production of baby spinach (Spinacia oleracea L.) leafy vegetable to nitrogen, phosphorus and potassium nutrition. J. Plant Nutr. (In press).

Neuhouser, M.L. 2004. Review: Dietary flavonoids and cancer risk: Evidence from human population studies. Nutr. Cancer 50:1-7.

Oren-Shamir, M., E. Gussakovsky, E. Eugene, A. Nissim-Levi, K. Ratner, R. Ovadia, and Y. Shahak. 2001. Coloured shade nets can improve the yield and quality of green decorative branches of Pittosporum variegatum. J. Hort. Sci. Biotechnol. 76:353-361.

Pellegrini, N., M. Serafini, B. Colombi, D. Del Rio, S. Salvatore, M. Bianchi, and F. Brighenti. 2003. Total antioxidant capacity of plant foods, beverages and oils consumed in Italy assessed by three different in vitro assays. J. Nutr. 133: 2812-2819.

Proteggente, A.R., A.S. Pannala, G. Paganga, L.V. Buren, E. Wagner, S. Wiseman, and C.A. RiceEvans. 2002. The antioxidant activity of regularly consumed fruit and vegetables reflects their phenolic and vitamin $\mathrm{C}$ composition. Free Radic. Res. 36:217-233.

Rodríguez-Hidalgo, S., F. Artés-Hernández, P.A. Gómez, J.A. Fernández, and F. Artés. 2010. Quality of fresh-cut baby spinach grown under a floating trays system as affected by nitrogen fertilisation and innovative packaging treatments. J. Sci. Food Agr. 90:1089-1097.

Selahle, M.K., D. Sivakumar, and P. Soundy. 2014. Effect of photo-selective nettings on postharvest quality and bioactive compounds in selected tomato cultivars. J. Sci. Food Agr. 94:2187-2195.

Shahak, Y., E.E. Gussakovsky, Y. Cohen, S. Lurie, R. Stern, S. Kfir, A. Naor, I. Atzmon, I. Doron, and Y. Greenblat-Avron. 2004. Colornets: A new approach for light manipulation in fruit trees. Acta Hort. 636:609-616.

Shahak, Y., E. Gal, Y. Offir, and D. Ben-Yakir. 2008. Photoselective shade netting integrated with greenhouse technologies for improved performance of vegetable and ornamental crops. International workshop on greenhouse environmental control and crop production in semi-arid regions. 797:75-80.

Shashirekha, M.N., S.E. Mallikarjuna, and S. Rajarathnam. 2015. Status of bioactive compounds in foods, with focus on fruits and vegetables. Crit. Rev. Food Sci. Nutr. 55: 1324-1339.

Stamps, R.H. 2009. Use of colored shade netting in horticulture. HortScience 44:239-241.

Toivonen, P.M. and D.A. Brummell. 2008. Biochemical bases of appearance and texture changes in fresh-cut fruit and vegetables. Postharvest Biol. Technol. 48:1-14.

Yoo, K.M., C.H. Lee, H. Lee, B. Moon, and C.Y. Lee. 2008. Relative antioxidant and cytoprotective activities of common herbs. Food Chem. 106:92-96.

Zhan, L., J. Hu, Y. Li, and L. Pang. 2012. Combination of light exposure and low temperature in preserving quality and extending shelf-life of fresh-cut broccoli (Brassica oleracea L.). Postharvest Biol. Technol. 72:76-81.

Zikalala, B.O., M. Nkomo, H. Araya, W. Ngezimana, and F.N. Mudau. 2016. Nutritional quality of baby spinach (Spinacia oleracea L.) as affected by nitrogen, phosphorus and potassium fertilization. S. Afri. J. Plant Soil. 34:79-86. 